\title{
A Study about Internet Addiction of University Students
}

\author{
Kerasioti Kassiani \\ Pliakou Evanthia \\ Vlachou Rafailia - Iro \\ Aspridis M. George* \\ Blanas Nikolaos \\ Tselios Dimitrios \\ Department of Business Administration, TEl of Thessaly \\ ${ }^{*}$ Corresponding Author
}

Doi: 10.2478/jesr-2018-0003

\begin{abstract}
Internet addiction is the most modern form of addiction and belongs to behavioral addictions. The term appeared in 1996 and spread very quickly all over the world, especially among teenagers and young people. Many users escape the formal use of the Internet and easily lose control of the situation. The article aims to deal with the university students' addiction to Internet and social media. It is a fact that most young people spend valuable time on the Internet without knowing the negative impact this engagement may have. For this purpose, a questionnaire based on the Internet Addiction Test was formulated, in order to answer a number of questions about Internet addiction, the consequences and causes of this phenomenon, the ways of dealing with the problem, the indications (information) and statistical data available for Greece, etc. The results obtained will be very useful and can be used by researchers to shape the profile of new and future uses, regarding the impact of internet use on professional life and development of young people, but also in dealing with social phenomena and adaptation problems.
\end{abstract}

Keywords : Internet, Addiction, Social Media, PC, Online

\section{Introduction}

Internet is a handy tool and it is a part of everyday life for all, especially young people. They obtain information, communicate and become active members of the global online community. Furthermore, Internet provides many opportunities for entertainment, information, searching and mailing. Internet users carry out online shopping, transactions with public services and banks, and participate in distance learning programs, but also improve the working conditions generally. In a globalized society, the Internet is an integral part of the everyday life of teenagers at all levels (Zhang, et al, 2015; Sfakianakis et al, 2012).

Internet does not only have a positive outlook though. On the contrary, Internet abuse often leads young people to various forms of addiction. Internet addiction is defined as "the inability to control the use of Internet that leads to feelings of pressure, anxiety and dysfunctional behaviors in everyday activities". The phenomenon of reckless use of the Internet by young people has taken 
enormous dimensions and has created problems for the mental and social functioning and it leads them to addiction (Tsitsika, 2013; Sfakianakis et al, 2012).

Internet addiction is one of the most recent forms of addiction recorded through Goldberg and Young surveys and is defined as "the forced and excessive use of the Internet and the irritation that occurs when the Internet is deprived" (Piperopoulos, 2002; Mitchell, 2000).

Subsequently, we will outline the basic conceptual boundaries of the dominant features of youth addiction on the Internet. Then we will describe the main findings of a recent survey on Internet addiction.

\section{Literature Review}

- Internet addiction belongs to so-called behavioral addictions. It is a broad term and it is occurred when the user has an unpleasant feeling when they do not exercise that behavior and feels well only when they do. Their behavior causes conflicts with the other members of their social environment and dominates their thoughts and actions. Although so far is not included in anyone of the official categories, so far in the textbooks of mental disorders, as it is a relatively new form of addiction, it is under review by the scientific community (Aspridis et al, 2016; Koulouras, 2015).

- Ivan Goldberg, a psychiatrist in New York, first used the term "Internet addiction" in 1996 at the American Psychology Congress and it was spreading rapidly, especially among teenagers and young people. According to Caplan and Sadock, in order to identify the disorder, a set of criteria should apply, such as "staying online for more and more time, and even more than the intended time, failure to manage the upcoming sensation of agitation or depression, risk of a relationship or opportunity loss due to the use, lies in order to cover the true extent of use, and finally use it, in order to control the negative feelings" (Aspridis et al, 2016; Manouselis, 2015; Sfakianakis et al, 2012).

- Internet has several uses. It can be distinguished in the typical use, for example a common working environment, sometimes for entertainment, and also in addiction, which is directly linked to the abuse of Internet and leads to the loss of control and the continuous use despite the consequences that might appear. Addictions of this type are online relationships and computer addiction and information overload (Aspridis et al, 2016; Tsitsika, 2013).

Internet addiction is a broad term and covers a wide range of behaviors and impulse control problems related to the use of Internet. The common element is that the individual disrupts their daily routine and is a psychopressive factor for his environment (Piperopoulos, 2002; Online available on the website http://www.georgefloros.com/page9.php).

The different types of addictions relate to the excessive use of adult websites for online sex, web sites for online relationships, social networks and chat rooms (MSN, etc.). Moreover, it also refers to the excessive use of online gambling and online shopping. Another category is the excessive browsing, i.e. the continuous and constant surfing on the Internet and databases' search. Finally, a special form (type) concerns (refers to) excessive engagement (occupation) with computers, persistence, that is, with online games and social networking pages, which are also the primary factors that lead to online addiction behaviors (Online available on the website http://www.georgefloros.com/page9.php).

Extensive Internet use has serious consequences to various aspects of human personality. There are many risks that threat on young people concerning Internet abuse, who are still at a sensitive developmental stage and they have not completed their character and personality formation. (Piperopoulos, 2002; Online available on the website http://www.georgefloros.com/page9.php).

\section{Previous Studies}

In an earlier research on "The world unplugged" (as cietd on 23-9-2013 in the Kathimerini newspaper), 1,000 students from around the world were asked not to use their devices for one day, 
so as to stay away from every source of information and communication. The students were coming from 12 Universities in 9 countries of the world. The participation was voluntary and at the end of the 24 hours they were obliged to report on their experiences. The results showed that most of the participants failed to complete the experiment, they had the feeling that the mobile and other devices were part of their body, the lack of use of social media raised loneliness, they could not discover other activities to pass their time, they are not interested in the current news but in the news of their friends and many others (as mentioned in Aspridis et al, 2016). According to the Newsweek magazine issue of 9 July 2012, a similar experiment was also carried out at the University of Maryland in 2010 involving 200 students, and according to the results students do not want to abstain from new technology and they cannot live without it (Aspridis et al, 2016).

In Greece, the use of social media is particularly widespread. According to Kathimerini newspaper (13/6/2015) the Facebook accounts exceed 6.5 million, Greeks spend at least 80 minutes per day at social media and most of them have an account with on them (as mentioned in Aspridis et al, 2016).

Finally, a survey conducted in autumn 2016 by the students of the Department of Business Administration revealed that the overwhelming majority of students could not stay away from the internet for a long time and have a strong desire to use social media tools and the Internet. They can also not replace the use of Internet with other activities (Aspridis et al, 2016).

\section{The Research Methodology}

The adopted methodology was quantitative as it was based on established questionnaires used in earlier surveys. Of course, the basic theoretical concepts on Internet addiction was presented first, the causes, consequences and ways of dealing with them, then the research questions were formulated, the questionnaire was distributed, the data were collected, the analysis was performed and the finally results were presented. The research was also exploratory and its purpose was to capture directly the views of the students about the use of the Internet and their addiction to it. The questionnaire is the most common research tool (Babbie, 2011; Saunders et al, 2009; Ronton et al, 2006; Dillman, 2000). The research population consists of the students of the Region of Thessaly and the Regional Unity of Thessaloniki. The sampling was done randomly and the size of the sample is equal to 200 questionnaire replies. Of course, the errors that need to be addressed are the tendency of the overgeneralization of the results and the risk of bias as a result of the sample error (Ront et al, 2006) due to its random generation.

The design of the research involved identifying the research problem and the research objectives. The formulation and generation of data collection tools, implementation of predicted sampling, collection and control and data processing, analysis of results, conclusions and proposals. Some students experienced difficulties in completing the questionnaire; they did not understand it, did not believe in its confidentiality and did not pay the necessary attention to complete it (Babbie, 2011).

The Internet Addiction Test (IAT) questionnaire was used as the basis for the survey (Online available on the website http://www.psychomed.gr/psychological-tests/internet-addictiontest/index.htm, Online available on the website Http://netaddiction.com/internet-addiction-test/). This specific questionnaire, which relates to the first certified online dependency measurement, has been adapted to the responses to measure the use of Internet by Greek students as follows : Not applicable, not applicable, not involved Rarely $\square$ Occasionally $\square$ Regularly Often $\square$ Always $\square$.

In the initial version of the questionnaire, the respondents is asked to answer the questions, sum up the results and extract the final result. The higher the degree, the higher the level of addiction and the greater the magnitude of problems arising from this use of Internet (Online available on the website http://dide.sam.sch.gr/keplinet/images/article-other /iat/iat.html).

The quantitative analysis followed was based solely on descriptive statistics, as already mentioned, the nature of the research was exploratory, while we used SPSS software that easily provides analytic descriptive statistics. 


\section{Presentation of the Results}

The survey was performed in May 2017. In total, we received 200 answers, of which 88 (44\%) were from male students and $112(56 \%)$ from female students. The age group was 18-25 and they are undergraduate students. The $24 \%$ of the answers came from Larissa, the $20 \%$ from Thessaloniki, the $14 \%$ from Trikala, the $22.5 \%$ from Karditsa and the $19.5 \%$ from Volos.

The $48 \%$ of the respondents said they were very often or always connected to Internet, while $30.5 \%$ of them said they were not connected or occasionally connected to Internet. The overwhelming majority of the students said they preferred their partner's company instead Internet use. This represents the $71.5 \%$ of the respondents. $47.5 \%$ of respondents replied that they never or almost never got complaints about the time they spent on Internet, as opposed to the $13.5 \%$ who said they were regularly get complaints. The $36 \%$ stated that checking their email is not the first thing to do, in contrast to the $29 \%$ that, which does it continuously. Following this question, the $49.5 \%$ of the respondents replied that they are not eager to connect to the internet, while the $13 \%$ said they were eager to connect to Internet and communicate. The $59 \%$ believe that their performance at work is not affected due to the use of Internet, while the $33 \%$ said they are strongly influenced.

Moreover, the $68,5 \%$ stated that rarely or never forms relationships with other Internet users, while the $11.5 \%$ said they do it often or always. Also, the $57.5 \%$ said they are defensive on questions they receive on Internet while the $12 \%$ said they are open to the questions and answer. The $38.5 \%$ of respondents replied that internet use does not help remove disturbing thoughts, while the $12.5 \%$ said that Internet use elicited positive thoughts.

The 53,5\% answered that they don't believe their life would be boring without internet, while the $18 \%$ stated they can not live without internet use, believing that their life would be vain. The $10.5 \%$ said they felt very annoyed when they were busy during their stay connected to Internet while the $64 \%$ said they were not particularly bothered. The numbers of those who are not sleeping due to late night Internet access coincide with those who responded that they do not have such an issue and are more specifically the $32 \%$ and the $36.5 \%$ respectively.

The $5 \%$ said they are often concerned about the Internet use, while they are not connected while the $70 \%$ said that this is rare or it does not happen. The $19.3 \%$ said is trying to reduce the time they are online but can not manage it and at the same time the $10 \%$ lies about the fact that they are connected to Internet from their relatives when the $8 \%$ prefer to work online longer than to use this time in social gatherings. The $7 \%$ of the respondents replied that their feelings were influenced by whether they were online, while the $67.5 \%$ replied the opposite. Finally, the $25.5 \%$ of the respondents answered that they neglected housework to remain connected to the Internet, while $35.5 \%$ replied that they did not or did so very rarely.

\section{Conclusions}

Internet offers incredible possibilities; it feeds us with information, news, entertainment, etc. It is a useful interactive tool, which facilitates our everyday life when used reasonably. The use of social networking sites, especially by the young people, should be done sparingly so as not to provoke extreme behaviors. A future expansion of the research will be further quantitative analysis of the collected data in order to identify the existence of correlations between answers to different questions, and if there are significant differences in the impact of Internet regarding sexes.

\section{References}

Aspridis, G., Blanas, N., and Tselios, D., (2016). «Social media: A modern drug». Eleftheria 13/11/2016 [in Greek].

Babbie, E., (2011). Introduction to social research. Athens : Kritiki [in Greek].

Dillman, D. A., (2000). Mail and internet surveys : The tailored design method. Vol. 2. N.Y. : Wiley.

Koulouras, G., (2015). Online addiction. Online available at http://www.cyberinsurancegreece.com/ethismos-stodiadiktyo/, was accessed on 9/8/2017 [in Greek].

Manouselis, Sp., (2016). Machine of the mind. Our online dependency. Online available at 
http://www.efsyn.gr/arthro/i-diadiktyaki-mas-exartisi, was accessed on 9/8/2017 [in Greek].

Mitchell, P., (2000). «Internet addiction : Genuine diagnosis or not». Lancet, Vol 355, No 9204, 632.

Zhang, Y., Mei, S., Chai, J., Li, J., and Du, H., (2015). "The relationship between impulsivity and internet addiction in Chinese college students : A moderated mediation analysis of meaning in life and selfesteem". PLoS One, 10(7).

Piperopoulos, G., (2002). Dependencies and deviations: Gambling, alcoholism, drug addiction, mental disorders, crime. Athens : Self-publishing [in Greek].

Rontos, K. and Rapanis, E., (2006). Statistical research: Methods and applications. Athens : Sideris [in Greek].

Saunders, M., Thornhill, A., and Lewis, A., (2009). Research methods for business students. $5^{\text {th }}$ edition, NY : Pearson.

Sfakianakis, E., Siomos, K., and Floros, Г., (2012). Internet addiction and other high-risk Internet behaviors. Athens : Livanis [in Greek].

Tsitsika, A., (2013). "Online addiction. The 6 warning signs". Online available at http://www.boro.gr/27580/ethismos-sto-diadiktyo-ta-6-proeidopoihtika-shmadia, was accessed on 9/8/2017 [in Greek].

\section{Online (Internet) resources}

http://www.psychomed.gr/psychological-tests/internet-addiction-test/index.htm, was accessed on 5/5/2017 [in Greek].

http://dide.sam.sch.gr/keplinet/images/article-other/iat/iat.html, was accessed on 5/5/2017 [in Greek].

http://netaddiction.com/internet-addiction-test/, was accessed on 5/5/2017.

http://youth-health.gr/thematikes-enotites/genika-gia-tin-efibeia/kataxrisi-diadiktuou-sumperiforeseksartisis\#.WYrM1ulLflU, was accessed on 9/8/2017 [in Greek].

http://www.boro.gr/27580/ethismos-sto-diadiktyo-ta-6-proeidopoihtika-shmadia, was accessed on 9/8/2017 [in Greek].

http://www.cyberinsurancegreece.com/ethismos-sto-diadiktyo/, was accessed on 9/8/2017 [in Greek].

http://www.efsyn.gr/arthro/i-diadiktyaki-mas-exartisi, was accessed on 9/8/2017 [in Greek].

http://www.georgefloros.com/page9.php, was accessed on 9/8/2017 [in Greek]. 


\section{Appendix}

Appendix $1:$ The questionnaire

I.1 : Sex (Answer by putting $\boldsymbol{X}$ in the corresponding checkbox)

\begin{tabular}{|l|l|}
\hline Male & \\
\hline Female & \\
\hline
\end{tabular}

I.2 : (In) Which age group (category) (do) you belong? (Answer by putting $\boldsymbol{X}$ in the corresponding checkbox)

\begin{tabular}{|l|l|}
\hline $18-25$ & \\
\hline $26-35$ & \\
\hline
\end{tabular}

I.3: What is the place of your studies? (In which city you study?) (Answer by putting $\boldsymbol{X}$ in the corresponding checkbox)

\begin{tabular}{|l|l|}
\hline Volos & \\
\hline Thessaloniki & \\
\hline Karditsa & \\
\hline 1. Larisa & \\
\hline Trikala & \\
\hline
\end{tabular}

3. How often do you stay online longer than you intended?

Not Applicable $\square$ Rarely $\square$ Occasionally $\square$ Frequently $\square$ Often $\square$ Always $\square$.

4. How often do you neglect household chores to spend more time online?

Not Applicable $\square$ Rarely $\square$ Occasionally $\square$ Frequently $\square$ Often $\square$ Always $\square$.

5. How often do you prefer the excitement of the Internet to come closer to with your partner?

Not Applicable $\square$ Rarely $\square$ Occasionally $\square$ Frequently $\square$ Often $\square$ Always $\square$.

6. How often do you form new relationships with fellow online users?

Not Applicable $\square$ Rarely $\square$ Occasionally $\square$ Frequently $\square$ Often $\square$ Always $\square$.

7. How often do others in your life complain to you about the amount of time you spend online?

Not Applicable $\square$ Rarely $\square$ Occasionally $\square$ Frequently $\square$ Often $\square$ Always $\square$.

8. How often do your grades or school work suffer because of the amount of time you spend online?

Not Applicable $\square$ Rarely $\square$ Occasionally $\square$ Frequently $\square$ Often $\square$ Always $\square$.

9. How often do you check your e-mail before something else that you need to do??

Not Applicable $\square$ Rarely $\square$ Occasionally $\square$ Frequently $\square$ Often $\square$ Always $\square$.

10. How often does your job performance or productivity suffer because of the Internet?

Not Applicable $\square$ Rarely $\square$ Occasionally $\square$ Frequently $\square$ Often $\square$ Always $\square$.

11. How often do you become defensive or secretive when anyone asks you what you do online?

Not Applicable $\square$ Rarely $\square$ Occasionally $\square$ Frequently $\square$ Often $\square$ Always $\square$.

12. How often do you block out disturbing thoughts about your life with soothing thoughts of the Internet?

Not Applicable $\square$ Rarely $\square$ Occasionally $\square$ Frequently $\square$ Often $\square$ Always $\square$.

13. How often do you find yourself anticipating when you will go online again?

Not Applicable $\square$ Rarely $\square$ Occasionally $\square$ Frequently $\square$ Often $\square$ Always $\square$.

14. How often do you fear that life without the Internet would be boring, empty, and joyless?

Not Applicable $\square$ Rarely $\square$ Occasionally $\square$ Frequently $\square$ Often $\square$ Always $\square$.

15. How often do you snap, yell, or act annoyed if someone bothers you while you are online?

Not Applicable $\square$ Rarely $\square$ Occasionally $\square$ Frequently $\square$ Often $\square$ Always $\square$.

16. How often do you lose sleep due to late-night log-ins

Not Applicable $\square$ Rarely $\square$ Occasionally $\square$ Frequently $\square$ Often $\square$ Always $\square$.

17. How often do you feel preoccupied with the Internet when off-line, or fantasize about being online?

Not Applicable $\square$ Rarely $\square$ Occasionally $\square$ Frequently $\square$ Often $\square$ Always $\square$.

18. How often do you find yourself saying "just a few more minutes" when online??

Not Applicable $\square$ Rarely $\square$ Occasionally $\square$ Frequently $\square$ Often $\square$ Always $\square$.

19. How often do you try to cut down the amount of time you spend online and fail?

Not Applicable $\square$ Rarely $\square$ Occasionally $\square$ Frequently $\square$ Often $\square$ Always $\square$.

20. How often do you try to hide how long you've been online?

Not Applicable $\square$ Rarely $\square$ Occasionally $\square$ Frequently $\square$ Often $\square$ Always $\square$.

21. How often do you choose to spend more time online over going out with others?

Not Applicable $\square$ Rarely $\square$ Occasionally $\square$ Frequently $\square$ Often $\square$ Always $\square$.

22. How often do you feel depressed, moody, or nervous when you are off-line, which goes away once you are back online?

Not Applicable $\square$ Rarely $\square$ Occasionally $\square$ Frequently $\square$ Often $\square$ Always $\square$. 